\title{
Emerging Roles of Perivascular Adipose Tissue in Regulation of Vascular Functions
}

\author{
Z. Yang* and J.P. Montani*
}

Department of Medicine, Division of Physiology, Faculty of Science, University of Fribourg, Switzerland

\begin{abstract}
Clinical and experimental studies provide increasing evidence that obesity is a major cardiovascular risk factor and that the adipose tissue is not just for regulation of lipid and energy homeostasis. Accordingly, the endocrine secretion of adipose tissue is implicated in the pathogenesis of vascular diseases. Whilst the functions of visceral and subcutaneous adipose tissue are relatively well studied, the role of perivascular adipose tissue in regulation of vascular functions is usually ignored. Emerging evidence indicates that perivascular adipose tissue is involved in the regulation of various physiological and pathological processes such as vascular smooth muscle contraction, vascular wall remodeling and inflammation, and, consequently, atherosclerosis and hypertension. Here we present an updated overview of vascular adipobiology, focusing on perivascular adipose tissue.
\end{abstract}

Key Words: Adipobiology, adipokines, atherosclerosis, contraction, smooth muscle cells, inflammation.

\section{INTRODUCTION}

Despite of recent progress in vascular biology and medicine, atherosclerotic cardiovascular disease remains the leading cause of death world wide [1,2]. Numerous risk factors such as hypercholesterolemia, hypertension, smoking, aging, and type 2 diabetes mellitus (T2DM) play important roles in the pathogenesis of atherosclerosis [3]. Among the risk factors, obesity has received much attention in recent years, because it is becoming a global public health problem of epidemic proportions [4,5]. Importantly, obesity is not only an independent cardiovascular disease risk factor [6,7], but also increases the potential of other risk factors clustered in the metabolic syndrome, such as hypertension, T2DM, dyslipidemia, and prothrombotic states, thus further facilitating the progression of atherosclerosis $[5,8]$. Although the link between obesity and cardiovascular disease is well documented, the underlying pathophysiological mechanisms remain elusive. Research in recent years provided compelling evidence suggesting that adipose tissue-secreted endocrine factors referred to as adipokines may indeed be an important link between obesity and cardiovascular disease [reviewed in 9].

Since the discovery of leptin in 1994 [10] adipose tissue is no longer considered as only an energy storage site. It is recognized as an important endocrine and paracrine organ producing a growing number of adipokines [11-13]. Adipokines are involved not only in the regulation of body weight and lipid metabolism, but also in insulin sensitivity, inflammation, thrombosis, and vascular endothelial and smooth muscle cell functions. The unfavorable changes in production in adipokines under certain pathological conditions such as obesity and obesity-associated metabolic disorders may play important roles in pathogenesis of atherosclerosis.

Adipose tissue from different locations in the body may exhibit different biological functions [14]. Indeed, patients with visceral adiposity are at high risk of developing insulin resistance, dyslipidemia, atherothrombosis and hypertension, pinpointing the intraabdominal visceral adipose tissue as the major culprits in these disorders [15-20]. Perhaps, this is related to a greater capacity of visceral adipose tissue to synthesize and release pro-atherogenic adipokines, compared to subcutaneous adipose tissue [21]; these aspects have been reviewed [22,23] and will not be discussed here.

Here we present an updated overview of vascular adipobiology, focusing on perivascular adipose tissue (PVAT). Although the

*Address correspondence to these authors at the Department of Medicine, Division of Physiology, University of Fribourg, Rue du Musée 5, CH-1700 Fribourg, Switzerland; Tel: 00412630085 93; Fax: 00412630096 36; E-mail: zhihong.yang@unifr.ch and Tel: 00412630085 91;

E-mail: jean-pierre.montani@unifr.ch interest in PVAT emerged only very recently [24], a couple of studies have provided supportive evidence that this tissue may play an important role in obesity-associated vascular disease by influencing smooth muscle cell (SMC) contraction, vascular structural remodeling, and vascular inflammation.

\section{PVAT REGULATES VASCULAR CONTRACTION}

Vascular contraction is primarily determined by the biological properties of medial SMC [25]. The function of vascular SMC is regulated by neuronal and hormonal mechanisms. In the past two decades much interest has been focused on the regulatory role of the inner layer of blood vessels, the endothelium, in regulation of vascular contraction [26]. Indeed, endothelial cells control vascular functions by releasing numerous factors that influence (i) SMC relaxation (e.g. nitric oxide, prostacyclin, endothelium-derived hyperpolarizing factor), (ii) SMC contraction (e.g. endothelin-1, thromboxane/endoperoxides), and (iii) SMC growth [27]. Conventional wisdom hold that the outermost layer of blood vessels, the PVAT, is solely for structural support of blood vessels and its possible role in the regulation of vascular functions was largely ignored. It was in 1991 when Soltis and Cassis [28] reported for the first time that PVAT can influence vascular contraction. These authors showed that the contractile responses to norepinephrine were significantly reduced in rat aortas with PVAT as compared to aortas in which PVAT was removed. No further research progress was made in this aspect of vascular biology during the following 10 years, until Löhn et al. [29] demonstrated in 2002 that peri-aortic adipose tissue produces a relaxing factor, tentatively dubbed adipose-derived relaxing factor (ADRF) [also see 30-32]. ADRF inhibits vascular contractions evoked by various vasoconstrictors such as serotonin, angiotensin II or phenylephrine [29]. The same group further revealed that the release of supposed relaxing factor(s) from perivascular fat surrounding rat aortas is dependent on $\mathrm{Ca}^{2+}$, protein tyrosine kinase, and protein kinase $\mathrm{A}$ [30]. The chemical nature of the relaxing factor(s) is largely unknown. It seems that it is a protein which causes vasorelaxation by opening ATP-dependent $\mathrm{K}^{+}$ $\left(\mathrm{K}_{\mathrm{ATP}}\right)$ channels in SMC. A similar observation was also described in rat small mesenteric arteries [31]. In this vascular bed, the perivascular fat inhibits vascular contraction through a relaxing factor(s) that also causes membrane hyperpolarisation via opening of a distinct type of $\mathrm{K}^{+}$channels namely voltage-dependent $\mathrm{K}^{+}$channels $(\mathrm{Kv})$. These results suggest that PVAT at different vascular bed may release different relaxing factors (Fig. 1). The production of vascular relaxant hyperpolarizing factor(s) from PVAT has also been confirmed in human internal thoracic arteries [32]. The physiological relevance of this relaxing factor is not yet clear. Its function is well preserved in a genetic obesity animal model, Zucker diabetic fatty (ZDF) rats [29], which are deficient in functional leptin receptors [33]. Whether there are adverse functional 
changes in perivascular fat in other animal models of obesity or obesity-related metabolic disorders as well as in, for example, spontaneously hypertensive rats (SHR) and Watanabe hereditary hyperlipidemic rabbits, warrants further investigation. Interestingly, a recent study reports that the offspring of Wistar rats receiving nicotine during pregnancy and lactation had increased postnatal body weight and an increased amount of PVAT in the thoracic aorta and mesenteric arteries as compared to offspring of control dams [34]. Vasoconstrictions to phenylephrine in aortas of offspring from control dams are reduced by PVAT. Importantly, this effect is, however, absent in the offspring of nicotine-exposed dams [34]. The results implicate that prenatal smoking could increase adiposity and decrease the production of the perivascular fat-derived relaxing factor(s), which may play a role in vascular dysfunction in children exposed to cigarette smoke in utero or in subjects with cigarette smoking [34].

Adipose tissue is an important source of pro-inflammatory cytokines such as tumour necrosis factor-alpha (TNF- $\alpha$ ), interleukin1beta (IL-1 $\beta$ ), and IL-6, and the chemokines monocyte chemoattractant protein-1 (MCP-1) and IL-8 [35] (Fig. 1). An increased production of these adipokines under obesity or obesity-associated diseases may be involved in vascular dyfunctions via interfering with insulin-mediated signaling pathways in endothelial cells as postulated recently by Yudkin and colleagues in their hypothesis of "vasocrine" signaling from perivascular fat (36). Insulin has been demonstrated to stimulate nitric oxide (NO) release via endothelial NO synthase (eNOS) causing vascular relaxation, and also influence endothelin-1 (ET-1) production in endothelial cells (37-41). Insulin-stimulated production of NO is mediated by insulin receptor/IRS/PI3K/Akt/eNOS pathway [39, 42,43] and ET-1 production is mediated by ERKs pathway [41,44]. Under physiological conditions the production of NO and ET-1 is balanced [40,45,46]. Through the release of endothelial NO, insulin may induce postprandial increase in blood flow in nutritive microcirculation favouring glucose uptake in the insulin target organs. However, with continued calorie excess and/or physical inactivity, vasoregulatory periarteriolar fat accumulates. Secretion of TNF- $\alpha$ from this perivascular fat may reduce endothelial NO release by interfering with PI3K/Akt/eNOS pathway, resulting in reduced insulin-induced vasodilatation or even vasoconstriction exerted by preserved production of ET-1 [44,47-49]. This imbalance of endothelium-derived vasoactive factors will reduce blood flow and substrate delivery to target organs, thereby, protects them from excess substrate delivery and further fat accumulation around vasculature. This may represent a sophisticated control mechanism to regulate postprandial substrate partition during conditions of calorie excess [36]. If this mechanism occurs in the vital organs such as heart, the epicardial adipose tissue, and particularly pericoronary adipose tissue, may enlarge and, consequently, such a protective mechanism might become harmful in cardiovascular biology.

\section{PVAT REGULATES VASCULAR REMODELING}

Besides the regulatory role in vascular tone, PVAT may also be involved in regulation of structural remodeling of the vascular wall. Arterial remodeling is defined as any enduring change in the size and/or composition of an adult blood vessel that allows blood vessels to adapt to the change in local blood flow pattern [50]. A negative remodeling underlines the pathogenesis of major cardiovascular diseases such as atherosclerosis, restenosis after vascular intervention, hypertension, and also vascular aging [51-54]. It is already recognized that negative vascular remodeling is primarily mediated by adventitial myofibroblasts [55-57]. SMC migration/proliferation from media toward the lumen and/or myofibroblast migration from adventitia and subsequent secretion of extracellular matrix components cause neointimal formation, a soil for atherosclerotic plaque growth [58]. Whether PVAT is also involved in vascular remodeling is at present unclear. Several growth factors released from adipose tissue cells and involved in the regulation of SMC prolifera- tion and/or migration have been identified. Examples of SMC growth promoters include lysophosphatidic acid [59, 60], angiotensin II [61], TNF- $\alpha$, leptin, fibroblast growth factor, insulin-like growth factor, and heparin-binding epidermal growth factor-like growth factor [62-64], whereas adiponectin is a SMC growth inhibitor [65] (Fig. 1). Adiponectin is the most abundant adipocytesecreted factor identified until now, and is the best characterized adipokine involved in vascular structural changes. Adiponectin increases insulin sensitivity, and its production is negatively associated with obesity, T2DM and coronary artery disease [66-71]. Adiponectin-deficient mice reveal pronounced insulin resistance and atherosclerosis and also greater neointimal proliferation after balloon injury than wild-type animals [72,73]. Whether perivascular adipocytes have the same functions in production of growth promoters and inhibitors as the adipocytes in other depots remains elusive.

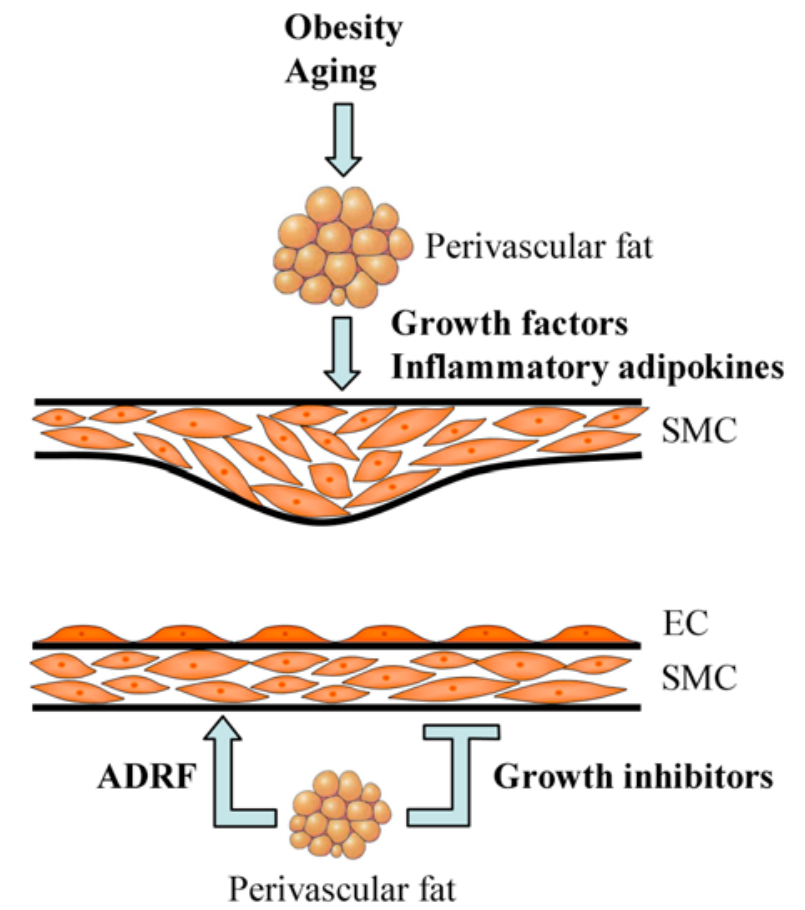

Fig. (1). Scheme illustrating the role of perivascular adipose tissue (PVAT) in the regulation of vascular functions. Under normal conditions (lower panel), PVAT produces adipose-derived relaxing factors (ADRF) and cell growth inhibitors, which prevent vasoconstriction and smooth muscle cell proliferation, respectively. Under the conditions of obesity and aging (upper panel), perivascular adipose depot enlarges and produces more inflammatory adipokines and growth factors, which damage endothelial cells and stimulate smooth muscle cell proliferation, resulting in vascular wall thickening and lumen narrowing. EC, endothelial cells; SMC, smooth muscle cells.

Our most recent study provided the first evidence suggesting that PVAT influences vascular SMC proliferation [74]. We demonstrated that differentiated but not undifferentiated adipocytes in culture stimulate SMC proliferation, which is in line with the finding by Manabe et al. [75] showing that mature primary adipocytes, but not preadipocytes, isolated from subcutaneous adipose tissue of Wistar rats stimulate breast cancer cell proliferation. We further demonstrated that PVAT also releases growth factor(s) stimulating SMC proliferation. The growth promoting effect of peri-aortic adipose tissue is significantly enhanced in aged rats (24 months) as compared to young rats ( 3 months), suggesting that it might be involved in age-associated vascular intimal thickening or negative vascular remodelling (Fig. 1). Furthermore, the SMC growth promoting effect of peri-aortic fat is also enhanced in the high-fat diet- 
induced obese WKY rats (Figure), but not in the genetically obese Zucker $f a / f a$ rats, which are deficient in functional leptin receptors. The contrasting results between the two obesity models might be due to the lack of effects of leptin in the obese Zucker fa/fa rats. Indeed, leptin presence positively correlates with cardiovascular risk [76,77]. The obese Zucker $\mathrm{fa} / \mathrm{fa}$ rats are relatively resistant to atherosclerosis and changes in vascular functions [78-80]. Also, the production of the newly suggested relaxing factor(s) released from peri-aortic adipose tissue in Zucker $f a / f a$ rats remains preserved as demonstrated recently [29].

The chemical nature of the SMC growth factor(s) released from mature adipocytes and PVAT has not yet been fully identified. Our experiments suggest that it is at least a heat- and trypsin-resistant hydrosoluble protein growth factor(s) with a molecular weight $>100$ $\mathrm{kD}$, which stimulates SMC proliferation synergistically with other growth promoters released from adipocytes or PVAT. It remains for future studies to identify the individual components released by PVAT and to investigate their functional roles in vascular remodeling under physiological and pathological conditions.

\section{PVAT REGULATES VASCULAR INFLAMMATION}

Obesity is associated with chronic low-grade inflammation, which has been shown to be a major pathogen of atherosclerosis [1]. Plasma concentrations of the pro- inflammatory mediators IL-6, TNF- $\alpha$, plasminogen activator inhibitor-1, and C-reactive protein (CRP) are elevated in obese patients [81-87]. Recent studies suggest that inflammation-related adipokines may contribute to the development and progression of atherosclerosis [9,24,71]. The role of PVAT in vascular inflammation is emerging (Fig. 1). It has been shown that inflammatory cells such as neutrophils and macrophages accumulated in the PVAT after vascular injury [88], and in human atherosclerosis, macrophages and $\mathrm{T}$ cells [89] and mast cells $[90,91]$ are located in PVAT, thus contributing to vascular inflammatory response in atherosclerosis. This hypothesis is supported by the experiments showing that conditioned medium from PVAT of human aortas is able to stimulate migration of white blood cells, mostly mediated by the adipose-secreted chemokines MCP-1/CCL2 (CCL, cysteine-cysteine motif chemokine ligand) and IL-8/CXCL8 [89]. The hypothesis of a putative local role of PVAT in atherogenesis has been supported by recent studies demonstrating higher levels of pro-inflammatory factors such as IL-1ß, MCP-1, TNF- $\alpha$, and resistin but lower levels of adiponectin expression in epicardial than subcutaneous adipose tissue [92,93]. Since abdominal adiposity is an independent predictor of cardiovascular risk [94], these observations may reinforce the hypothesis that adipose tissueaccumulated inflammatory cells [88-90,95-97] may play an important role in obesity-related atherosclerosis. One important lesson that could be learned from the recent PVAT studies is that we should no longer remove it from the artery wall, but keep it attached and in place, and subject to thorough examinations, as recently postulated [24].

\section{CONCLUSIONS}

We reviewed recent evidence implicating the regulatory role of PVAT in vascular biology, focusing on PVAT-derived adipokines and vascular tone, SMC proliferation, and vascular inflammation. Yet, many lessons remain to be learned from PVAT and its paracrine contribution to vascular physiology and pathology. Accordingly, new experimental approaches which can specifically modify PVAT functions (e.g. PVAT-depleted mice and ADRFdeficient mice) without altering those of adipose tissues at other locations should be developed in future studies of vascular adipobiology.

\section{ACKNOWLEDGEMENTS}

The own original results reported in this article were supported by Swiss National Science Foundation (Nr. 3100A0-105917/1),
AETAS Foundation and Swiss Heart Foundation. There was no conflict of interest.

\section{REFERENCES}

[1] Libby, P.; Theroux, P. Circulation, 2005, 111, 3481.

[2] He, J.; Gu, D.; Wu, X.; Reynolds, K.; Duan, X.; Yao, C.; Wang, J.; Chen, C S.; Chen, J.; Wildman, R. P.; Klag, M. J.; Whelton, P. K. N. Engl. J. Med. 2005, 353, 1124.

[3] Yusuf, S.; Hawken, S.; Ounpuu, S.; Dans, T.; Avezum, A.; Lanas, F.; McQueen, M.; Budaj, A.; Pais, P.; Varigos, J; Lisheng, L.; INTERHEART Study Investigators. Lancet, 2004, 364, 937.

[4] Eckel, R.H.; York, D.A.; Rossner, S.; Hubbard, V.; Caterson, I.; St Jeor, S.T.; Hayman, L.L.; Mullis, R.M.; Blair, S.N. Circulation, 2004, 110, 2968.

[5] Grundy, S. M. Circulation, 2002, 105, 2696.

[6] Hubert, H. B.; Feinleib, M.; McNamara, P. M.; Castelli, W. P. Circulation, 1983, 67, 968 .

[7] Poirier, P.; Eckel, R. H. Curr. Atheroscler. Rep., 2002, 4, 448.

[8] McGill, H.C.; Jr., McMahan, C.A.; Herderick, E.E.; Zieske, A.W.; Malcom, G.T.; Tracy, R.E.; Strong, J.P. Circulation, 2002, 105, 2712.

[9] Lau, D.C.; Dhillon, B.; Yan, H.; Szmitko, P.E.; Verma, S. Am. J. Physiol. Heart Circ. Physiol., 2005, 288, H2031.

[10] Zhang, Y.; Proenca, R.; Maffei, M.; Barone, M.; Leopold, L.; Friedman, J.M. Nature, 1994, 372, 425.

[11] Trayhurn, P. Acta Physiol. Scand., 2005, 184, 285.

[12] Ahima, R.S.; Flier, J.S. Trends Endocrinol. Metab., 2000, 11, 327

[13] Chaldakov, G.N.; Stankulov, I.S.; Hristova, M.; Ghenev, P.I. Curr. Pharm. Des., 2003, 9, 1023.

[14] Montani, J. P.; Carroll, J. F.; Dwyer, T. M.; Antic, V., Yang, Z.; Dulloo, A. G. Int. J. Obes. Relat Metab Disord., 2004, 28 Suppl 4, S58.

[15] Carey, D. G.; Jenkins, A. B.; Campbell, L. V., Freund, J.; Chisholm, D. J. Diabetes, 1996, 45, 633.

[16] Kanai, H.; Tokunaga, K.; Fujioka, S.; Yamashita, S.; Kameda-Takemura, K. K.; Matsuzawa, Y. Hypertension, 1996, 27, 125.

[17] Nieves, D.J.; Cnop, M.; Retzlaff, B.; Walden, C.E.; Brunzell, J.D.; Knopp, R H.; Kahn, S.E. Diabetes, 2003, 52, 172

[18] Shimomura, I.; Funahashi, T.; Takahashi, M.; Maeda, K.; Kotani, K.; Nakamura, T.; Yamashita, S.; Miura, M.; Fukuda, Y.; Takemura, K.; Tokunagea, K; Matsuzawa, Y. Nat. Med., 1996, 2, 800.

[19] Yusuf, S.; Hawken, S.; Ounpuu, S.; Bautista, L.; Franzosi, M.G.; Commerford, P.; Lang, C. C.; Rumboldt, Z.; Onen, C. L.; Lisheng, L.; Tanomsup, S.; Wangai, P.; Jr., Razak, F.; Sharma, A.M.; Anand, S.S.; INTERHEART Study Investigators. Lancet, 2005, 366, 1640.

[20] Panagiotakos, D. B.; Pitsavos, C.; Yannakoulia, M.; Chrysohoou, C.; Stefanadis, C. Atherosclerosis, 2005, 183, 308.

[21] Bruun, J.M.; Lihn, A.S.; Madan, A.K.; Pedersen, S.B.; Schiott, K.M.; Fain, J. N.; Richelsen, B. Am. J. Physiol Endocrinol. Metab., 2004, 286, E8.

Wajchenberg, B.L. Endocr. Rev., 2000, 21, 697.

Arner, P. Biochem. Soc. Trans., 2001, 29, 72. Stankulov, I.S.; Aloe, L.; Ghenev, P.I.; Manni, L.; Pavlov, P.; Fiore, M.; Chaldakov, G.N. Biomed. Rev., 2002, 13, 63.

[25] Hirano, K.; Hirano, M.; Kanaide, H. J. Smooth Muscle Res., 2004, 40, 219

[26] Yang, Z.; Ming, X.-F. Clin. Med. Res., 2006, 4, 53.

[27] Yang, Z.; Luscher, T.F. In PanVascular Medicine, Lanzer, Ed.; Springer Berlin - Heidelberg - New York, 2002; pp.190-204.

[28] Soltis, E.E.; Cassis, L.A. Clin. Exp. Hypertens., 1991, 13, 277.

[29] Lohn, M.; Dubrovska, G.; Lauterbach, B.; Luft, F.C.; Gollasch, M.; Sharma, A. M. FASEB J., 2002, 16, 1057.

[30] Dubrovska, G.; Verlohren, S.; Luft, F. C.; Gollasch, M. Am. J. Physiol. Heart Circ. Physiol., 2004, 286, H1107.

[31] Verlohren, S.; Dubrovska, G.; Tsang, S.Y.; Essin, K.; Luft, F. C.; Huang, Y.; Gollasch, M. Hypertension, 2004, 44, 271.

[32] Gao, Y.J.; Zeng, Z.H.; Teoh, K.; Sharma, A.M.; Abouzahr, L.; Cybulsky, I.; Lamy, A.; Semelhago, L.; Lee, R.M. J. Thorac. Cardiovasc. Surg., 2005, 130,1130 .

[33] Phillips, M. S.; Liu, Q.; Hammond, H. A.; Dugan, V.; Hey, P. J.; Caskey, C. J.; Hess, J. F. Nat. Genet., 1996, 13, 18.

[34] Gao, Y. J.; Holloway, A. C.; Zeng, Z. H., Lim, G. E.; Petrik, J. J.; Foster, W. G.; Lee, R. M. Obes. Res., 2005, 13, 687.

[35] Berg, A. H.; Scherer, P. E. Circ. Res., 2005, 96, 939.

[36] Yudkin, J. S.; Eringa, E.; Stehouwer, C. D. Lancet, 2005, 365, 1817.

[37] Scherrer, U.; Randin, D.; Vollenweider, P., Vollenweider, L.; Nicod, P. J. Clin. Invest., 1994, 94, 2511.

[38] Misurski, D. A.; Wu, S. Q.; McNeill, J. R.; Wilson, T. W.; Gopalakrishnan, V. Hypertension, 2001, 37, 1298.

[39] Zeng, G.; Nystrom, F. H.; Ravichandran, L. V.; Cong, L. N.; Kirby, M.; Mostowski, H.; Quon, M. J. Circulation, 2000, 101, 1539.

[40] Verma, S.; Yao, L.; Stewart, D. J.; Dumont, A. S.; Anderson, T. J.; McNeill, J. H. Hypertension, 2001, 37, 328.

[41] Formoso, G.; Chen, H.; Kim, J. A.; Montagnani, M.; Consoli, A.; Quon, M. J. Mol. Endocrinol., 2005, Dec 22, (Epup ahead of print).

[42] Montagnani, M.; Chen, H.; Barr, V. A.; Quon, M. J. J. Biol. Chem., 2001, 276, 30392. 
Hartell, N. A.; Archer, H. E.; Bailey, C. J. Biochem. Pharmacol., 2005, 69, 781.

[44] Potenza, M. A.; Marasciulo, F. L.; Chieppa, D. M.; Brigiani, G. S.; Formoso, G.; Quon, M. J.; Montagnani, M. Am. J. Physiol Heart Circ. Physiol., 2005, 289, H813.

[45] Cardillo, C.; Nambi, S. S.; Kilcoyne, C. M.; Choucair, W. K., Katz, A.; Quon, M. J.; Panza, J. A. Circulation, 1999, 100, 820.

[46] Misurski, D. A.; Wu, S. Q.; McNeill, J. R.; Wilson, T. W.; Gopalakrishnan, V. Hypertension, 2001, 37, 1298.

[47] Wallis, M. G.; Wheatley, C. M., Rattigan, S.; Barrett, E. J.; Clark, A. D.; Clark, M. G. Diabetes, 2002, 51, 3492.

[48] Vincent, M. A.; Montagnani, M.; Quon, M. J. Curr. Diab. Rep., 2003, 3, 279.

[49] Miller, A. W.; Tulbert, C.; Puskar, M.; Busija, D. W. Hypertension, 2002, 40, 78.

[50] Galis, Z. S.; Khatri, J. J. Circ. Res., 2002, 90, 251

[51] Pasterkamp, G.; Galis, Z. S.; de Kleijn, D. P. Arterioscler. Thromb. Vasc. Biol., 2004, 24, 650.

[52] Birkenhauer, P.; Yang, Z.; Gander, B. J. Pharm. Pharmacol., 2004, 56, 1339.

[53] Glasser, S. P. Heart Dis., 2000, 2, 375.

[54] Laurant, P.; Adrian, M.; Berthelot, A. Can. J. Physiol Pharmacol., 2004, 82, 269.

[55] Mintz, G. S.; Kent, K. M., Pichard, A. D.; Satler, L. F.; Popma, J. J.; Leon, M. B. Circulation, 1997, 95, 1791.

[56] Schwartz, R. S.; Topol, E. J.; Serruys, P. W.; Sangiorgi, G.; Holmes, D. R.; Jr. J. Am. Coll. Cardiol., 1998, 32, 2087.

[57] Sangiorgi, G.; Taylor, A. J.; Farb, A.; Carter, A. J.; Edwards, W. D.; Holmes, D. R.; Schwartz, R. S.; Virmani, R. Am. Heart J., 1999, 138, 681.

[58] Schwartz, S. M. Circ. Res., 1999, 85, 877.

[59] Pages, G.; Girard, A.; Jeanneton, O.; Barbe, P.; Wolf, C.; Lafontan, M.; Valet, P.; Saulnier-Blache, J. S. Ann. N. Y. Acad. Sci., 2000, 905, 159.

[60] Gennero, I.; Xuereb, J. M., Simon, M. F.; Girolami, J. P.; Bascands, J. L.; Chap, H., Boneu, B.; Sie, P. Thromb. Res., 1999, 94, 317.

[61] Schling, P.; Mallow, H.; Trindl, A.; Loffler, G. Int. J. Obes. Relat. Metab. Disord., 1999, 23, 336.

[62] Schling, P.; Loffler, G. News Physiol. Sci., 2002, 17, 99.

[63] Oda, A.; Taniguchi, T.; Yokoyama, M. Kobe J. Med. Sci., 2001, 47, 141

[64] Matsumoto, S.; Kishida, K.; Shimomura, I.; Maeda, N.; Nagaretani, H.; Matsuda, M.; Nishizawa, H.; Kihara, S.; Funahashi, T.; Matsuzawa, Y.; Yamada, A., Yamashita, S.; Tamura, S.; Kawata, S. Biochem. Biophys. Res. Commun., 2002, 292, 781.

[65] Matsuda, M.; Shimomura, I.; Sata, M.; Arita, Y.; Nishida, M.; Maeda, N.; Kumada, M.; Okamoto, Y.; Nagaretani, H.; Nishizawa, H.; Kishida, K.; Komuro, R.; Ouchi, N.; Kihara, s.; Nagai, R.; Funahashi, T.; Matasuzawa, Y. J. Biol. Chem., 2002, 277, 37487.

[66] Pischon, T.; Girman, C. J.; Hotamisligil, G. S., Rifai, N.; Hu, F. B.; Rimm, E. B. JAMA, 2004, 291, 1730.

[67] Arita, Y.; Kihara, S.; Ouchi, N.; Takahashi, M.; Maeda, K.; Miyagawa, J.; Hotta, K.; Shimomura, I.; Nakamura, T., Miyaoka, K.; Kuriyama, H.; Nishida, M.; Yamashita, S., Okubo, K.; Matsubara, K.; Muraguchi, M.; Ohmoto, Y.; Funahashi, T.; Matsuzawa, Y. Biochem. Biophys. Res. Commun., 1999, $257,79$.

[68] Balagopal, P.; George, D.; Yarandi, H.; Funanage, V.; Bayne, E. J. Clin. Endocrinol. Metab., 2005, 90, 6192.

[69] Kumada, M.; Kihara, S.; Sumitsuji, S.; Kawamoto, T.; Matsumoto, S.; Ouchi, N.; Arita, Y.; Okamoto, Y.; Shimomura, I.; Hiraoka, H.; Nakamura, T.; Funahashi, T.; Matsuzawa, Y.; Osaka CAD Study Group, Coronary artery disease. Arterioscler. Thromb. Vasc. Biol., 2003, 23, 85.

[70] Weyer, C.; Funahashi, T.; Tanaka, S.; Hotta, K.; Matsuzawa, Y.; Pratley, R. E.; Tataranni, P.A. J. Clin. Endocrinol. Metab., 2001, 86, 1930.
[71] Iacobellis, G.; Pistilli, D.; Gucciardo, M.; Leonetti, F.; Miraldi, F.; Brancaccio, G.; Gallo, P.; di Gioia, C.R. Cytokine, 2005, 29, 251.

[72] Kubota, N.; Terauchi, Y.; Yamauchi, T.; Kubota, T.; Moroi, M.; Matsui, J.; Eto, K.; Yamashita, T.; Kamon, J.; Satoh, H.; Yano, W.; Froguel, P.; Nagai, R.; Kimura, S.; Kadowaki, T.; Noda, T. J. Biol. Chem., 2002, 277, 25863.

[73] Yamauchi, T. Kamon, J. Waki, H.; Imai, Y.; Shimozawa, N.; Hioki, K. Uchida, S.; Ito, Y.; Takakuwa, K.; Matsui, J.; Takata, M.; Eto, K.; Terauchi, Y.; Komeda, K.; Tsunoda, M.; Murakami, K.; Ohnishi, Y.; Naitoh, T.; Yamamura, K.; Ueyama, Y.; Froguel, P.; Kimura, S.; Nagai, R.; Kadowaki, T. J. Biol. Chem., 2003, 278, 2461

[74] Barandier, C.; Montani, J. P.; Yang, Z. Am. J. Physiol. Heart Circ. Physiol., 2005, 289, H1807.

[75] Manabe, Y.; Toda, S.; Miyazaki, K.; Sugihara, H. J. Pathol., 2003, 201, 221.

[76] Correia, M. L.; Haynes, W. G. Curr. Opin. Nephrol. Hypertens., 2004, 13, 215.

[77] van der Vleuten, G. M.; Veerkamp, M. J.; van Tits, L. J.; Toenhake, H.; den, H. M.; Stalenhoef, A. F.; de, G. J. Atherosclerosis, 2005, 183, 355.

[78] Amy, R. M.; Dolphin, P. J.; Pederson, R. A.; Russell, J. C. Atherosclerosis, 1988, 69, 199.

[79] Bohlen, H. G.; Lash, J. M. Am. J. Physiol., 1995, 268, H2366.

[80] Shimamura, T.; Amorosa, L. F.; Wilson, A. C.; Lelkes, L.; Khachadurian, A K. Jpn. J. Exp. Med., 1990, 60, 105.

[81] Ghanim, H.; Aljada, A.; Hofmeyer, D.; Syed, T.; Mohanty, P.; Dandona, P. Circulation, 2004, 110, 1564

[82] Kern, P. A.; Ranganathan, S.; Li, C.; Wood, L.; Ranganathan, G. Am. J. Physiol Endocrinol. Metab., 2001, 280, E745.

[83] Juhan-Vague, I.; Alessi, M. C.; Vague, P. Diabetologia, 1991, 34, 457.

[84] Hauner, H.; Bender, M.; Haastert, B.; Hube, F. Int. J. Obes. Relat. Metab. Disord., 1998, 22, 1239.

[85] Vozarova, B.; Weyer, C.; Hanson, K.; Tataranni, P.A.; Bogardus, C.; Pratley, R.E. Obes. Res., 2001, 9, 414

[86] Dandona, P.; Weinstock, R.; Thusu, K.; Abdel-Rahman, E.; Aljada, A.; Wadden, T. J. Clin. Endocrinol. Metab., 1998, 83, 2907.

[87] Piche, M. E.; Lemieux, S.; Weisnagel, S. J.; Corneau, L.; Nadeau, A.; Bergeron, J. Am. J. Cardiol., 2005, 96, 92.

[88] Okamoto, E.; Couse, T.; De, L.H.; Vinten-Johansen, J.; Goodman, R. B.; Scott, N. A.; Wilcox, J. N. Circulation, 2001, 104, 2228

[89] Henrichot, E.; Juge-Aubry, C. E.; Pernin, A.; Pache, J.C.; Velebit, V.; Dayer, J. M.; Meda, P.; Chizzolini, C.; Meier, C.A. Arterioscler. Thromb. Vasc. Biol., 2005, 25, 2594

[90] Chaldakov, G.N.; Fiore, M.; Stankulov, I.S.; Manni, L.; Hristova, M.G.; Antonelli, A.; Ghenev, P.I.; Aloe, L. Prog. Brain Res., 2004, 146, 279.

[91] Chaldakov, G.N.; Tonchev, A.B.; Tuncel, N., Attanasova, P.; Aloe L. In Adipose Tissue and Adipokines in Health and Disease. Fantuzzi, G.; Mazzone, T., Ed.;Humana Press Inc.: Totowa, NJ, USA, 2006, in press.

[92] Mazurek, T.; Zhang, L.; Zalewski, A.; Mannion, J. D.; Diehl, J.T.; Arafat, H.; Sarov-Blat, L.; O'Brien, S.; Keiper, E.A.; Johnson, A.G.; Martin, J.; Goldstein, B. J.; Shi, Y. Circulation, 2003, 108, 2460.

[93] Baker, A.R.; Silva, N.F.; Quinn, D.W.; Harte, A.L.; Pagano, D.; Bonser, R.S.; Kumar, S.; McTernan, P.G. Cardiovasc. Diabetol., 2006, 5, 1.

[94] Nguyen-Duy, T.B.; Nichaman, M.Z.; Church, T.S.; Blair, S.N.; Ross, R. Am. J. Physiol. Endocrinol. Metab., 2003, 284, E106.

[95] Weisberg, S.P.; McCann, D.; Desai, M.; Rosenbaum, M.; Leibel, R.L.; Ferrante, A.W., Jr. J. Clin. Invest., 2003, 112, 1796.

[96] Xu, H.; Barnes, G. T.; Yang, Q.; Tan, G.; Yang, D.; Chou, C.J.; Sole, J.; Nichols, A.; Ross, J. S.; Tartaglia, L. A.; Chen, H. J. Clin. Invest., 2003, 112, 1821.

[97] Curat, C. A.; Miranville, A.; Sengenes, C., Diehl, M.; Tonus, C., Busse, R.; Bouloumie, A. Diabetes, 2004, 53, 1285 . 